April 2007

\title{
Naming Horror: Legal and Political Words for Mass Atrocities
}

Martha Minow

Follow this and additional works at: https://digitalcommons.usf.edu/gsp

\section{Recommended Citation}

Minow, Martha (2007) "Naming Horror: Legal and Political Words for Mass Atrocities," Genocide Studies and Prevention: An International Journal: Vol. 2: Iss. 1: Article 5.

Available at: https://digitalcommons.usf.edu/gsp/vol2/iss1/5

This Articles is brought to you for free and open access by the Open Access Journals at Digital Commons @ University of South Florida. It has been accepted for inclusion in Genocide Studies and Prevention: An International Journal by an authorized editor of Digital Commons @ University of South Florida. For more information, please contact digitalcommons@usf.edu. 


\title{
Naming Horror: Legal and Political Words for Mass Atrocities
}

\author{
Martha Minow \\ Jeremiah Smith, Jr., Professor, Harvard Law School
}

We live at a time when journalists coin phrases like "compassion fatigue" to describe failures of ordinary outrage and human action against massive killings, famines, and plagues. Our is a time when mass media and the Internet offer unprecedented connections among people-and when the top "hits" for Internet searches of "atrocity" and "nameless crime" each produce the Web sites of rock bands, ${ }^{1}$ even as the ongoing and vicious brutalities in the Darfur region of the Sudan escalate and Rwanda, Cambodia, Sierra Leone, and still other regions stagger to recover from the legacies of their own mass atrocities. Other nations participate in the creation and operation of ad hoc and long-term international criminal institutions, and at times use the United Nations' cumbersome mechanisms to name and even condemn mass violence, but fail to provide swift and effective action to prevent or mitigate mass atrocities.

In this context, one can only welcome David Scheffer's thoughtful and practical call to separate the political and legal uses of "genocide" and to devise the broader category of "atrocity crimes" for public communication about genocide, crimes against humanity, and war crimes. Scheffer's essay represents the kind of scholarship on vital international affairs that is most needed. Every page reveals both his on-the-ground experience as US ambassador-at-large for war crimes and US representative to the United Nations and his analytic care. His report of barriers to effective action in response to recent experiences of genocide and mass violence is compelling and distressing. He identifies four problems: first, the legal requirements for establishing what is a genocide are stringent and cumbersome and contribute to delays in international responses; second, the absence of a well-developed idea of stages prior to but leading to genocide similarly contributes to delays in international responses; third, the reliance on legal terms in political discourse confuses the demands of each realm; and, fourth, there is no easy public term for the collection of horrors that lawyers name "genocide," "crimes against humanity," and harms of comparable seriousness and massiveness. Therefore, Scheffer recommends the development of new terms, including "precursors of genocide" and "atrocity crimes."

The frustration behind Scheffer's effort is palpable and telling, and the failures of national and international response deserve much more serious attention than they have received. ${ }^{2}$ But the problems he addresses will not be cured by new words. It is a matter of some interest that a person of Scheffer's wisdom and expertise should put his emphasis in that direction. That choice in itself deserves some discussion, but the necessary energy would be better spent pursuing better leadership, better media and educational efforts to mobilize sustained public responsiveness, and the development of a richer spectrum of available responses to join national and international efforts to halt mass and dehumanizing violence. I will try to elaborate through three comments. 


\section{First, as attractive as "naming" may seem for changing perceptions and behavior, renaming legal categories will do little to address underlying problems of leadership and will}

Satisfying legal criteria for genocide for purposes of prosecution is difficult. Diplomats thinking of launching interventions can get caught up in anticipating the legal difficulties while something that appears to be a genocide unfolds. But attributing delays and reluctance to mount national and international responses seems a mistake, given the more obvious sources of reluctance in apathy, fear, self-interest, and perceived futility on the parts of national leaders and their constituents. Blaming the legal categories here is like blaming the legal categories of tort law for the national and international failures to deal with global warming. The cure will not come from new words. Instead, we need better leadership and a spectrum of responses to join national and international efforts to halt mass and dehumanizing violence.

Scheffer perceptively describes the laborious process of defining a particular atrocity as a genocide ${ }^{3}$ and attributes the tardiness of national and international response to this difficulty. He cites the example of Darfur, with eighteen months passing before the US government named the mass killings and ethnic cleansing in that region a genocide. Yet, as Scheffer himself states, the obstacles to mobilizing a national or international response did not disappear, and, in fact, seemed to increase, after the American determination of genocide. The hopes of advocates that the name "genocide" would propel the United States to act were dashed. The explanation for this seems to be that the very label implied such an enormous evil that the United States would have had to be ready to commit as many troops, as much money, and as many diplomatic resources as might be necessary to stop it-with no assurances as to when or how such intervention would succeed.

Fears that responding to mass violence will require too much sacrifice, at too high a cost, or with little assurance of efficacy, explain the failures of response more persuasively than confusion over whether the events underway deserve the label "genocide" or that of "crimes against humanity." Even if labeling were the issue, "crimes against humanity" is already a label that calls for serious response. Indeed, in its reference to murder, extermination, enslavement, deportation, and persecution, the definition of crimes against humanity overlaps with the definition of genocide and surely crosses whatever threshold people may need to indicate horrors of the most severe order.

The focus on names is understandable, but it is too limited to meet the underlying concerns. In particular, new names will not undo the reluctance of individuals, nations, and international organizations to respond to mass violence; this reluctance has many sources, but no small contribution comes from fear about what is required for a full and effective response.

Now, why should Scheffer focus on words? It could be that the development of "genocide" as a category—and the story of Raphael Lemkin's one-person campaign—is so inspiring that a new campaign, with new words, seems promising. ${ }^{5}$ Indeed, Lemkin's is a heroic tale, and nongovernmental groups as well as UN agencies and nation-states can now engage in different kinds of debates because there is now a category for the intentional effort to eliminate an entire group of people. Lemkin rightly identified first the mass killings of Armenians and then the Holocaust as atrocities of a specific nature-plans to destroy a whole people - that had no prior label; that is not the difficulty today, in part because the international community then developed the notions of genocide and crimes against humanity. In addition, we now 
have the object lesson of our experience with the invention of the legal category of genocide. That word generated a convention and diplomatic activities, but its existence has not halted the numbers or rate of horrors that fit under its definition. There is no evidence from this instance that a word alone will make the difference in mobilizing action. And unless words alone make the difference, there is no reason to believe that a new phrase would not fall victim to the same dynamic-a sense of enormous stakes met with reluctance to interfere in another nation's activities, reluctance to go down the road that leads to military action.

Perhaps Scheffer means to tap into the sense of urgency and condemnation that comes when a collection of events in the world becomes understood as violating fundamental human rights. Something in this direction may have happened when the international criminal tribunals began to acknowledge mass rapes as evidence of genocide. 6 In a different context, the legal terms "sexual harassment" and "environmental racism" have provided legal and practical avenues for addressing harms that people had experienced but that had not been condemned through public institutions. ${ }^{7}$ Those of us who have chosen legal careers hope that law can mobilize action and produce change. But the hammer of legal categories does not make everything a nail. Our own specific professional expertise may, in fact, be a very limited contribution to addressing massive problems. Work on political mobilization, more thoughtful media messages that reduce the risk of "compassion fatigue," analysis of strategic political interests capacious enough to include reputation and humanrights values, and the development of a range of sanctions and other tools are among the directions that seem more likely to reach the roots of the failures of nations to act in response to mass atrocity.

The risk of overemphasizing lawyers' categories as solutions should not obscure the degree to which existing law actually can, with the right leadership, accomplish a fair amount of what Scheffer wants. For example, the new phrase "precursors to genocide" is meant to fill a gap and to trigger earlier recognition of actions giving rise to a genocide, before large numbers of killings have occurred. Yet even without that phrase, the current legal framework already recognizes, condemns, and authorizes prosecution and punishment for steps on the way to genocide: article 3 of the UNCG criminalizes

(b) Conspiracy to commit genocide;

(c) Direct and public incitement to commit genocide;

(d) Attempt to commit genocide;

(e) Complicity in genocide.

These terms may not fully communicate to political leaders and ordinary citizens the warning signals of severe violations of human rights, however, and communication along these lines may be what Scheffer means to prompt by devising the concept of "precursors to genocide." Similarly, it would help if states could generate more options than verbal condemnation, economic sanctions, and military action in order to meet early warning signals of potential genocides with proportionate and meaningful responses.

\section{Second, for public communication, the term "atrocity crime" loses the specificity of "genocide" and "crimes against humanity" without offering clarity in return}

For ease of communication, I certainly understand Scheffer's reasons for proposing a general category of "atrocity crimes" to group together what currently get the labels 
"genocide," "crimes against humanity," and "war crimes." Yet despite his hope to break free from legalistic definitions, I find myself wondering about the exact referents for "atrocity crimes." Would the phrase simply scoop up all acts currently covered by genocide, crimes against humanity, and war crimes? Only some of them? Or more than them? Some of the confusion comes from the fact that the term "atrocity" is already in use: in the Nuremberg Tribunal's definition of "crimes against humanity," in definitions of grave breaches of the Geneva Conventions, ${ }^{9}$ and in at least one nation's effort to define universal jurisdiction. ${ }^{10}$

Even in writing this short commentary, I have struggled to find words to describe the topic of concern and have at times used "atrocity," "massive killings," and "massive violence." None of the terms is adequate. Using "genocide," however, taps into the hard-won arguments about the truly heinous nature of orchestrated efforts to destroy a people. "Crimes against humanity" has the benefit of underscoring that the interests of all of humanity are at stake and also the unacceptability of denying the humanity of victims. ${ }^{11}$ A general term would be useful to identify the range of these offenses, plus war crimes, and "atrocity" may be as good as any; but perhaps the very awkwardness of locution should remain-as a partial acknowledgment of the incommensurability of human language and responses to the horrors at hand. ${ }^{12}$

\section{Third, doing something to get people to think and act is crucial}

I endorse entirely Scheffer's effort to stand back from particular conflicts to consider what national and global initiatives could lift us from the dismal patterns that join heinous violence with tardy and insufficient international responses. Even if others join me in criticizing his particular proposals, he has accomplished no small part of his goal if he gets people to engage with the difficulties. The debate makes me think we need to spend more time understanding the sources of resistance-by individuals, by nations, by international organizations-if we are to devise more meaningful and timely responses to mass atrocities.

\section{Acknowledgments}

I thank my first-year reading group on crimes against humanity and Karen Naimer for conversations prompted by David Scheffer's paper, and Herb Hirsch for inviting me to contribute to this issue. Thanks to Seth Kipp and Kristin Flower for research help.

\section{Notes}

1. See ATROCITY, official home page, http://www.atrocity.de (accessed 3 January 2007); Nameless Crime, official home page, http://www.namelesscrime.com (accessed 3 January 2007).

2. For thoughtful treatments, see Stanley Cohen, States of Denial: Knowing about Atrocities and Suffering (Cambridge: Polity Press, 2001); Susan Moeller, Compassion Fatigue: How the Media Sell Disease, Famine, War and Death (New York: Routledge, 1999); Linda Melvern, Conspiracy to Murder: The Rwanda Genocide and the International Community (London: Verso, 2006); Roméo Dallaire, Shake Hands with the Devil: The Failure of Humanity in Rwanda (New York: Carroll \& Graf, 2005); Pierre Bourdieu, ed., The Weight of the World: Social Suffering in Contemporary Societies (Oxford: Polity Press, 1999); Luc Boltanski, Distant Suffering: Morality, Media and Politics (Cambridge: Cambridge University Press, 1999).

3. See Convention on the Prevention and Punishment of the Crime of Genocide, 9 December 1948, 78 U.N.T.S. 277 (UNCG), article 2: "In the present Convention, genocide means any 
of the following acts committed with intent to destroy, in whole or in part, a national, ethnical, racial or religious group, as such:

(a) Killing members of the group;

(b) Causing serious bodily or mental harm to members of the group;

(c) Deliberately inflicting on the group conditions of life calculated to bring about its physical destruction in whole or in part;

(d) Imposing measures intended to prevent births within the group;

(e) Forcibly transferring children of the group to another group.

See also Rome Statute of the International Criminal Court, UN Doc. A/CONF.183/9 (17 July 1998), art. 6.

4. Article 7 of the Rome Statute of the International Criminal Court, UN Doc. A/CONF.183/9 (17 July 1998), also includes apartheid and other crimes of the same seriousness as extermination, mass murder, and group persecution.

5. See Samantha Power, "A Problem from Hell": America and the Age of Genocide (New York: HarperPerennial, 2003).

6. Prosecutor v. Karadzic and Mladic, Review of the Indictment Pursuant to Rule 61 of the Rules of Procedure and Evidence, ICTY-95-5-R61 and ICTY-95-18-R61, paras. 94-95 (11 July 1996); Prosecutor v. Akayesu, Judgment, ICTR-96-4-T (2 September 1998).

7. Robert D. Bullard, ed., Confronting Environmental Racism: Voices from the Grassroots (Boston: South End Press, 1993); Penn Loh and Jodi Sugerman-Brozan, "Environmental Justice Organizing for Environmental Health: Case Study on Asthma and Diesel Exhaust in Roxbury, Massachusetts," Annals of the American Academy of Political and Social Science 584 (2002): 110-22, 112.

8. Art. 3(1)(c), Trials of War Criminals Before the Nuremberg Military Tribunal Under Control Council Law No. 10 (1952), xviii. See Matthew Lippman, "The Convention on the Prevention and Punishment of the Crime of Genocide," Arizona Journal of International and Comparative Law 15 (1998) 415-93, 431, n. 100 (comparing this definition to the definition of "crimes against humanity" in art. 6(c) of the Nuremberg charter, which did not require connecting the atrocity to a crime aginst peace or a crime of war).

9. Geneva Convention Relative to the Protection of Civilian Persons in Time of War, 23 May 1969, 75 U.N.T.S. 287, http://www.unhchr.ch/html/menu3/b/92.htm (accessed 3 January 2007), art. 146; see Mark Osiel, "Obeying Orders: Atrocity, Discipline and the Law of War," California Law Review 86 (1998): 939-1017, 951-53, noting how "atrocity" defines manifestly illegal acts in military laws, sometimes refers to exceptionally serious war crimes, and lacks common scope in different uses.

10. Human Rights Watch, Belgium: Questions and Answers on the "Anti-Atrocity" Law, Revised June 2003, http://www.hrw.org/campaigns/icc/belgium-qna.pdf (accessed 16 January 2007).

11. David Luban, "A Theory of Crimes against Humanity," Yale Journal of International Law 29 (2004): 85-167.

12. See Saul Friedlander, "Trauma, Memory, and Transference," in Holocaust Remembrance: The Shapes of Memory, ed. Georffrey H. Hartman, 252-63 (Oxford: Blackwell, 1994), $252,261$. 